\title{
MINERAL RESOURCE POTENTIAL OF THE BLANCO MOUNTAIN AND BLACK CANYON ROADLESS AREAS, INYO AND MONO COUNTIES, CALIFORNIA
}

\author{
SUMMARY REPORT \\ By \\ Michael F. Diggles and Richard J. Blakely
U.S. Geological Survey \\ and
}

Richard L. Rains and Steven W. Schmauch

U.S. Bureau of Mines

\section{STUDIRS RELATED TO WILDERNESS}

Under the provisions of the Wilderness Act (Public Law 88-577, September 3, 1964) and related acts, the U.S. Geological Survey and the U.S. Bureau of Mines have been conducting mineral surveys of wilderness and primitive areas. Areas officially designated as "wilderness," "wild," or "canoe" when the act was passed were incorporated into the National Wilderness Preservation System, and some of them are presently being studied. The act provided that areas under consideration for wilderness designation should be studied for suitability for incorporation into the Wilderness System. The mineral surveys constitute one aspect of the suitability studies. The act directs that the results of such surveys are to be made available to the public and be submitted to the President and the Congress. This report discusses the results of a mineral survey of the Blanco Mountain (5059) and Black Canyon (5061) Roadless Areas, Inyo National Forest, Inyo and Mono Counties, California. The areas were established as further planning areas during the Second Roadless Area Review and Evaluation (RARE II) by the U.S. Forest Service, January 1979.

\section{SUMMARY}

On the basis of geologic, geochemical, and geophysical investigations and a survey of mines and prospects, the mineral resource potential for gold, silver, lead, zinc, tungsten, and barite of the Blanco Mountain and Black Canyon Roadless Areas is judged to be low to moderate, except for one local area that has high potential for gold and tungsten resources.

A geochemical survey detected moderately anomalous amounts of lead, copper, and zinc and less anomalous concentrations of tungsten, gold, and silver. Elements in anomalous samples were grouped as suites known to form in various ore deposits. Four element suites that may be indicative of mineralization are recognized in the White Mountains: (1) lead, zinc, and silver in carbonate rocks; (2) copper, barite, and lead in veins and replacement bodies; (3) tungsten, molybdenum, and bismuth in skarns; and (4) gold and arsenic in mineralized quartz veins. The assessment of the areas of resource potential was made in part by the application of ore deposit models to the geochemical results.

A mineral deposit survey by the U.S. Bureau of Mines indicates that there are no properties with identified mineral resources in the Blanco Mountain Roadless Area. There is one active placer claim. In the Black Canyon Roadless Area, two properties have 40,000 tons of indicated and inferred low-grade gold, silver, or lead-bearing rock. Five properties near this roadless area have 150,000 tons of indicated and inferred low-grade gold, silver, lead, zinc, or tungsten-bearing rock. About 90 percent of this tonnage is estimated to occur at the Mirage-Mariposa and the Hope mines.

The roadless areas have no known resource potential for geothermal energy, coal, oil, or gas.

\section{INTRODUCTION}

\section{Location and access}

The Blanco Mountain and Black Canyon Roadless Areas encompass approximately $27 \mathrm{mi}^{2}$ and $48 \mathrm{mi}^{2}$, respectively, in the Inyo National Forest in Inyo and Mono Counties, California (fig. 1). The Black Canyon Roadless Area is $6 \mathrm{mi}$ east, and the Blanco Mountain Roadless Area is $20 \mathrm{mi}$ northeast of Bishop. The terrain is rugged and steep, with relief of about $6,000 \mathrm{ft}$ along most of the west side of the White Mountains. Elevation ranges from $11,278 \mathrm{ft}$ at Blanco Mountain to about $4,500 \mathrm{ft}$ in Owens Valley to the west of the range. The climate is arid to semi-arid, and at least two climatic life zones are present because of the great range in elevation. Most of the vegetation is typical of the Upper Sonoran and Transition zones, consisting of sagebrush, rabbitbrush, and sparse grasses at lower elevations and pinon pine, juniper, and mountain mahogany on mountain slopes. At higher elevations limber pine and bristlecone pine are present; the highest parts of the White Mountains are above timberline. Perennial vegetation along streams includes willow, aspen, wild rose, and grasses.
Access to the Blanco Mountain Roadless Area and east side of the Black Canyon Roadless Area is by the road to the University of California research station on Mount Barcroft. Spur roads following Wyman Creek and part of the Crooked Creek drainages provide access to most of the perimeter of the Blanco Mountain Roadless Area. Several roads lead east from Bishop to the western and interior parts of the Black Canyon Roadless Area.

\section{Previous and present studies}

California State Mineralogist and State Mining Bureau publications by Hanks (1884), Fairbanks (1894), Crawford $(1896 a, b, c)$ and Aubury (1904) recorded information on the producing mines in the areas. The most complete early geologic studies on the White Mountains are a report by Knopf (1914) and a comprehensive general study by Knopf that contains a section by Kirk (in Knopf, 1918) that contains a bibliography that includes geologic studies published prior to 1918. Updated information on local mines is given by Tucker (1926), Tucker and Sampson (1938), Eric, (1948), and Norman and Stewart (1951). 
During the 1960's and 1970 's, the U.S. Geological Survey published detailed geologic maps of this area at a scale of 1:62,500. Most of the two roadless areas are covered by the Blanco Mountain quadrangle mapped by Nelson (1966b). Remaining parts of the area are covered by geologic maps of the Bishop and Big Pine quadrangles (Bateman, 1965), Waucoba Mountain quadrangle (Nelson, 1966a), and the Mount Barcroft quadrangle (Krauskopf, 1971). A number of reports describing the stratigraphy, structure, economic geology, hydrology, and other aspects of White Mountain geology have also been published. A geologic map of the roadless areas within the White Mountains was compiled by McKee and others (1982). Additional studies related to granitic rocks in the area are included in Anderson (1937), Emerson (1966), and Crowder and others (1973). Stratigraphic and paleontologic studies of the area include Nelson (1962), Nelson and Durham (1966), and McKee and Gangloff (1969).

The U.S. Geological Survey carried out field investigations in the summer of 1980 . The work included field checking existing geologic maps and geochemical sampling. A total of 386 stream-sediment, 363 panned heavymineral, and 302 rock samples were collected for chemical analysis and provide the geochemical data base for this report. Results of these analyses and statistical summaries were presented by Diggles and others (1982).

The U.S. Bureau of Mines conducted an extensive library search, supplemented by several unpublished or private information sources obtained mostly through claim owners. U.S. Forest Service and U.S. Bureau of Land Management records supplied information on current mining claims. All of the Inyo and Mono County mining claim records were reviewed and those pertaining to the roadless areas were organized by drainage or geographical area and plotted on base maps. Field studies by Bureau of Mines from June to October 1981 identified 53 mining properties, from which 665 samples were collected. Samples were analyzed by fire-assay, atomic-absorption, and inductively-coupled argonplasma-spectrophotometry methods. At least one sample from each property was analyzed by semiquantitative spectrography. A summary of the results of these studies are in open-file reports by Schmauch and others (1982) and by Rains and others (1983). Additional analytical data and detailed property maps are on file at the U.S. Bureau of Mines Western Field Operations Center in Spokane, Washington.

\section{GEOLOGY}

Rocks in the roadless areas range from upper Proterozoic sedimentary types to unconsolidated Holocene deposits. These can be divided into four major groups: (1) Upper Proterozoic through Cambrian strata consisting of a sequence of carbonate, sandstone, and shale deposited in a shallow-marine continental-shelf environment; (2) Mesozoic plutonic rocks of the Inyo batholith, an eastern extension of the Sierra Nevada batholith that consists predominantly of granite (nomenclature of Streckeisen, 1976); (3) Upper Tertiary, mainly Miocene and Pliocene, volcanic rocks consisting of olivine basalt flows found in the Blanco Mountain Roadless Area; and (4) Quaternary stream and alluvial fan deposits.

The Proterozoic rocks comprise most of four formations that are composed of about equal amounts of carbonate and quartzose clastic rocks. The oldest rocks are phyllites with minor fine-grained sandstone and interbedded dolomite of the Wyman Formation. Unconformably overlying these rocks is the gray, fine- to medium-grained, mediumbedded Reed Dolomite, which is conformable with the overlying Deep Spring Formation. The Deep Spring Formation consists of mostly limestone and dolomite at the bottom and quartzite and shale at the top. Locally, the youngest Proterozoic rocks belong to the lower part of the Andrews Mountain Member of the Campito Formation; the Andrews Mountain Member is a thick sequence of dark, thinto medium-bedded blocky quartzite.

The lowest Cambrian strata comprise the upper part of the Andrews Mountain Member and the Montenegro Member of the Campito, which consists of thin-bedded siliceous siltstone and has yielded the lowest occurrence of olenellid trilobites in the region. The Blanco Mountain Roadless Area contains only these Proterozoic and Cambrian units. The Black Canyon Roadless Area contains additional Paleozoic rocks. The Poleta Formation conformably overlies the Campito Formation and consists of medium-bedded to massive limestone at its base, and shale, quartzite, and thinto medium-bedded limestone in its upper part. The Harkless Formation overlies the Poleta, but is not entirely exposed in the Black Canyon Roadless Area. The Harkless Formation consists mostly of siltstone, quartzite, and local limestone beds and is in thrust contact with the Emigrant Formation, which is composed of shale, thin-bedded silty limestone.

Granitic rocks crop out over about a third of the Blanco Mountain Roadless Area and in a small part of the Black Canyon Roadless Area. The granitic rocks intrude and locally metamorphose the thick section of older sedimentary rocks. The plutons generally have sharp contacts and are typically surrounded by contact-metamorphic aureoles a few hundred feet wide. The Blanco Mountain Roadless Area contains two granitic plutons, the Beer Creek and the Sage Hen Flat plutons. The Beer Creek pluton is Jurassic in age and consists of medium- to coarse-grained porphyritic rock with large euhedral orthoclase phenocrysts. The Sage Hen Flat pluton is a medium-grained, quartz-poor rock of Jurassic and (or) Cretaceous age. A small granitic pluton in the Black Canyon Roadless Area is in Redding Canyon. It is composed of coarse-grained porphyritic quartz monzonite of Jurassic and (or) Cretaceous age.

Upper Tertiary volcanic rocks are mainly mediumgray, fine-grained, and locally vesicular olivine basalt and some andesites that occur in scattered locations in the northern half of the Blanco Mountain Roadless Area. The discontinuous perched outcrops are remnants of once extensive lava flows that locally cover stream gravels. These areas have since been uplifted and deeply eroded.

At least three distinct periods of deformation are recognized in the roadless areas. The oldest structures are found only in the Proterozoic and Paleozoic strata and record a period of thrusting before emplacement of the Inyo batholith. The thrusting event displaced relatively younger Cambrian strata over relatively older Cambrian rocks that elsewhere in the White Mountains are conformable. The second period of deformation is related to the emplacement of the Mesozoic Inyo batholith. Local deformation is related to the various plutonic intrusions that comprise this batholith. The third phase of deformation, involving Tertiary through Holocene basin and range block faulting, is responsible for the present configuration of the White Mountains. The White Mountains are one of the best examples of a block-faulted range in the Basin and Range physiographic province.

\section{GEOCHEMICAL STUDIES}

Diggles (1983) described the geochemical anomalies detected in roadless areas within the White Mountains. That summary of the geochemical results showed that one pannedconcentrate sample from the Blanco Mountain Roadless Area yielded anomalous amounts of molybdenum and bismuth. These elements are associated with mineralized skarns and suggest that tungsten may occur as well. The Reed Dolomite-Sage Hen Flat pluton contact, which the drainage crosses, is a likely place for skarn type of deposits.

Fourteen drainages in the Black Canyon Roadless Area produced anomalous amounts of a few elements in pannedconcentrate samples. These drainages form two groups. The area between Silver Canyon and Poleta Canyon contained a few samples with anomalous amounts of lead, copper, zinc, gold, silver, and tungsten. Samples from the Marble Canyon area contained a few anomalies of gold, silver, lead, copper, zinc, and tungsten. No anomalies were found in the unconcentrated samples from this area.

The results of the geochemical survey indicate that mineralization occurs primarily as (1) silver, lead, and zinc in carbonate rocks; (2) lead, copper, and barite in veins, replacement bodies; (3) tungsten, molybdenum, and bismuth from a possible skarn zone; and (4) gold and arsenic in mineralized quartz veins. 


\section{GEOPHYSICAL STUDIRS}

Aeromagnetic data provides information on rock type and structure at depth and helps delineate the subsurface contacts between plutonic and sedimentary rocks in the study area. This is important in a mineral resource assessment because certain igneous-sedimentary contacts are the site of mineralization.

An aeromagnetic survey was flown along east-west flight lines spaced $1 \mathrm{mi}$ apart and at a constant barometric altitude of $14,000 \mathrm{ft}$ across the White Mountains. The data produced by this survey were compiled into contour maps of total magnetic field anomalies from which the following geophysical interpretations were made.

In the Blanco Mountain Roadless Area, the Beer Creek and Sage Hen Flat plutons create a distinctive magnetic anomaly. The magnetic intensity patterns suggest that the southwest margin of the Beer Creek pluton dips to the southwest below the Wyman Formation and other Proterozoic, as well as Paleozoic sedimentary rocks. This anomaly extends over the granite of Sage Hen Flat, indicating that the Proterozoic sedimentary rocks separating the Beer Creek pluton from the Sage Hen Flat pluton form only a thin septum.

A broad magnetic low occurs over the widespread Proterozoic and Paleozoic sedimentary rocks at the southern end of the White Mountains, suggesting that the sedimentary rocks are very thick and that plutonic rocks are not present near the surface. Small plutons, such as the Redding Canyon pluton, do not produce significant magnetic anomalies.

\section{MINING ACTIVITY}

Three principal mining districts within the Black Canyon Roadless Area are the Bishop, Black Canyon, and Poleta districts. Eleven other mining districts, the Big Pine, Bishop Creek, Deep Springs, Laws, Marble Canyon, Pine Mountain, Redding Canyon, Silver Canyon, Westgard Pass, White Mountains, and Wyman Creek districts, are partially within the Black Canyon and Blanco Mountain Roadless Areas.

Mining activity began in the White Mountains in the early 1860's, but no claims were filed in the Blanco Mountain

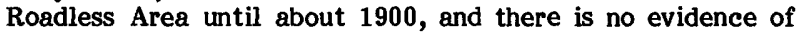
earlier prospecting. At least 31 lode claims and 18 placer claims were filed on 11 properties in this area. The most recent lode claim was filed in 1977; one group of three placer claims is active. There are no mines with recorded production in or near the Blanco Mountain Roadless Area.

Since 1879, about 740 mining claims have been located within the Black Canyon Roadless Area. Sixteen of these were placer claims. The only patented mining claim, which covers the Poleta mine, is located just outside the roadless area. According to U.S. Bureau of Land Management records, 53 lode claims are active.

The first reported mining activity was in the 1860 's, when the Little Gem (also called Georgia and X-Ray) mine (loc. 13) was worked (Knopf, 1918). The gold ores from the Little Gem and Gray Eagle mines (loc. 15) were processed in an arrastra in Redding Canyon.

The Mirage-Mariposa (Golden Mirage) mine (loc. 14) was first worked in 1912. Five carloads of gold-bearing ore were shipped from this mine and from the Gray Eagle and Little Gem mines in 1912 (Knopf, 1914).

During the 1950 's, scheelite-bearing rock was discovered at the $\mathbf{R}$ and $\mathbf{R}$ mine, outside the roadless area. In 1952, several thousand tons of ore of unknown grade were produced and shipped to the Round Valley Tungsten Company (Bateman, 1956). An estimated 20,000 tons of rock and ore has been removed from the glory hole of the $R$ and $R$ mine. The property is currently known as the Mirage-Mariposa mine.

The Grand Central, Star Wano, and Golden Jubilee claims were surveyed for patent in 1907 and were collectively named the Black Canyon Consolidated mine, sometimes referred to as the Black Canyon mine. Aubury (1904) reported that the mine had unspecified lead-silver production. The property is currently known as the Trinity prospect (loc. 29).

The Poleta mine (loc. 6), adjacent to the Black Canyon Roadless Area, is one of the oldest mines in the area and provided the mining excitement of 1881 (Chalfont, 1933) when it was patented. By 1896 , ore was being processed by water driven arrastra. During the following $\mathbf{5 0}$ years, several people owned or operated the mine and mill and by 1938, a 12-ton per day ball mill with a 96 percent recovery rate had processed 4,000 tons of ore (Tucker and Sampson, 1938). The Poleta mine idle from 1941 to 1958 , was in operation from 1958 to 1962 , and is currently idle.

Another mining operation just outside the Black Canyon Roadless Area was the Mineral Point-Sanger-Hope group, sometimes referred to as the Hope group (loc. 28). Nothing is known about the property before 1920. In 1925, the Hope group was leased to W. A. Sanger and Robert Swank and later to the Tonopah Dividend Mining Company of San Francisco, Calif. From 1930 to 1950 , it was known as the Eagle and Westward Eagle No. 2. U.S. Bureau of Land Management records show Argus Resources as claimants of the Hope since 1946. In 1947, Morr is Albertoli and Associates of Big Pine, Calif., operated the property. In 1980, Dean Karlberg located the Carol J mine (loc. 25) on part of the property. This property has sometimes been referred to as the Black Canyon mine or group. It is not to be confused with the Black Canyon Consolidated mine which is now known as the Trinity prospect.

Most of the production from the Black Canyon Roadless Area was from 1880 to about 1900, when gold was mined, from 1925 to 1947 when gold, silver, lead, and some copper were mined, and in the 1950's when tungsten was mined. The Poleta mine produced gold and silver from 1892 to 1962 . During the 1950 's, two properties were developed on a scheelite deposit. Production records are incomplete and the grade is not known. Two mines in, and six mines adjacent to the Black Canyon Roadless Area have had production (table 1). Records are not available for production prior to 1891.

Mines and prospects examined during this study are shown on figure 2 and on the accompanying map. Summary descriptions for all properties are in table 2. Those with mineral resource potential are underlined. Mineral resource classifications used in this table are from U.S. Bureau of Mines and U.S. Geological Survey (1980). Indicated and inferred resource categories reflect degrees of geologic assurance and sample density. Properties for which no resources were calculated because of the lack of sufficient geologic control are also included in this table because they may contain undiscovered resources.

lt is not likely that many of the mines with small reserves could operate profitably as single entities. Given favorable economic conditions, however, it is possible for several groups of mines with indicated and inferred resources to operate through centrally located processing facilities. Because of the relatively small tonnages at the individual properties, these mines could best be developed by smallscale mining operations.

\section{MINERAL RESOURCE ASSESSMENT}

Geochemical samples of stream sediment, panned concentrate, and rock were collected and analyzed from all drainages in the roadless areas (Diggles, 1983). Groups of elements that are known to commonly occur together including silver-lead-zinc, tungsten-molybdenum-bismuth, gold-arsenic, and copper-lead, were plotted on a map. From this information, areas with metal anomalies were identified. Site-specific studies of mines and prospects provided additional information for defining areas with resource potential.

Eight areas within the Blanco Mountain and Black Canyon Roadless Areas are identified as having anomalous amounts of various metals in stream-sediment samples and the location of areas with mineral resource potential are shown on figure 2 . 
Black Canyon Roadless Area

Area A

Samples from a small drainage between Poleta Canyon and Silver Canyon contain anomalous amounts of tungsten, gold, silver, antimony, lead, and barite. These metals are probably derived from mineralized quartz veins and barite veins in metasedimentary rocks. The Sand A Gold and Barite Queen prospects in this area have gold and barite in veins. A tungsten anomaly from an older alluvial deposit may have been derived from skarns or quartz veins that eroded to produce the alluvial deposit. The mineral resource potential for area A is low for gold, lead, silver, zinc, and barite.

\section{Areas B and C}

Gold-bearing veins in granite were mined in the Gray Eagle mine (loc. 15) inside the roadless area in Redding Canyon and in the Mirage-Mariposa and Little Gem mines (locs. 14 and 13 respectively) outside the roadless area. The past-producing mines in the vicinity suggest area B has moderate resource potential and area $C$ has high resource potential for gold. Area $\mathrm{C}$ also has a high resource potential for tungsten.

\section{Area D}

In the upper Black Canyon drainage, the Hope and Carol $\mathrm{J}$ mines (locs. 28 and 25 respectively) produced silver, lead, zinc, and gold from replacement-ore zones in carbonate rocks. Area D has moderate resource potential for silver, lead, zinc, and gold.

\section{Area E}

Stream-sediment samples from three tributaries on the south side of Black Canyon contained anomalous amounts of lead, silver, and gold. Prospects in this area, including the Hall Extension (loc. 35), were developed on lead and silverbearing quartz veins in carbonate rocks. The Trinity prospect (loc. 29) is on a sheared quartzite-dolomite contact zone that contained gold-bearing quartz veins.

Area $\mathrm{E}$ has low resource potential for lead, silver, and zinc in carbonate rocks and for gold in quartz veins associated with shear zones in quartzite and dolomite.

\section{Blanco Mountain Roadless Area}

\section{Areas $\mathrm{F}$ and $\mathrm{G}$}

Two mines northwest of the roadless area and the Blizzard Extension prospect (loc. 43) in the roadless area were developed on mineralized parts of the contact zone between the Reed Dolomite and the Sage Hen Flat pluton. Small gold-bearing quartz veins crop out on both rock types in the contact area at the Blizzard Extension prospect. Geochemical sampling showed tungsten and bismuth anomalies in both areas. Area $G$ has a moderate resource potential for gold in vein deposits. Areas $F$ and $G$ have low resource potential for tungsten in skarn deposits.

Area $\mathrm{H}$

On the east side of the roadless area, erosional remnants of Tertiary olivine basalt flows cover parts of a south-flowing early(?) Tertiary stream channel. Mining in this area has yielded an unknown and probably small amount of gold from placer deposits. Area $\mathrm{H}$ has a low potential for additional gold in placer deposits.

\section{REPERENCES CTTED}

Anderson, G.H., 1937, Granitization, albitization, and related phenomena in the northern Inyo Range of CaliforniaNevada: Geological Society of America Bulletin, v.48, p. 1-74.

Aubury, L. E., 1904, Map and register of mines and minerals of Inyo County, California: California State Mining Bureau, Louisiana Purchase Exposition.

Bateman, P. C., 1956, Economic geology of the Bishop tungsten district, California: California Division of Mines and Geology Special Report 47, 87 p.

1965 , Geology and tungsten mineralization of the Bishop district, California: U.S. Geological Survey Professional Paper 470, $208 \mathrm{p}$.

Chalfant, W. A., 1933, The story of Inyo: Bishop, California, Chalfant Press Inc., $430 \mathrm{p}$.

Crawford, J. J., 1896a, Argentiferous galena: California State Mining Bureau, Thirteenth report of the State Mineralogist, p. 32-34.

1896b, Gold: California State Mining Bureau, Thirteenth report of the State Mineralogist, p.64-503.

-1896c, Marble, limestone, and lime: California State Mining Bureau, Thirteenth report of the State Mineralogist, p. 627-633.

Crowder, D. F., McKee, E. H., Ross, D. C., and Krauskopf, K. B., 1973, Granitic rocks of the White Mountains area, California-Nevada: age and regional significance: Geological Society of America Bulletin, v. 84, p. 285-296.

Diggles, M. F., 1983, Map and interpretation of geochemical anomalies in the White Mountains, Blanco Mountain, Birch Creek, and Black Canyon Roadless Areas, White Mountains, California and Nevada: U.S. Geological Survey Miscellaneous Field Studies Map MF-1361-B, scale $1: 62,500$.

Diggles, M. F., Dellinger, D. A., Sutley, S. J., Fey, D. L., and Hill, R. H., 1982, Chemical data for samples of rock, stream-sediment, and nonmagnetic dense-mineral concentrate in the White Mountains, Blanco Mountain, Birch Creek, and Black Canyon Roadless Areas, White Mountains, California and Nevada: U.S. Geological Survey Open-File Report 82-984, 188 p.

Emerson, D. O., 1966, Granitic rocks of the Mt. Barcroft quadrangle, California-Nevada: Geological Society of America Bulletin, v. 77, p. 127-152.

Eric, J. H., 1948, Tabulation of copper deposits of California, in Copper in California by Jenkins, O. P., ed: California Division of Mines Bulletin 144, p.197-357.

Fairbanks, H. W., 1894, Preliminary report on the mineral deposits of Inyo, Mono, and Alpine Counties: California State Mining Bureau, Annual Report of the State Mineralogist, v. 12, p. 472-478.

Hanks, H. G., 1884, Catalogue and description of the minerals of California as far as known, with special reference to those having an economic value: California State Mining Bureau, Annual Report of the State Mineralogist, v. 4, p. 61-398.

Knopf, Adolph, 1914, Mineral resources of the Inyo and White Mountains, California: U.S. Geological Survey Bulletin 540 , pt. 1, p. 81-121.

1918, A geologic reconnaissance of the Inyo Range and the eastern slope of the Sierra Nevada, California, with a section on The stratigraphy of the Inyo Range, by Edwin Kirk: U.S. Geological Survey Professional Paper $110,130 \mathrm{p}$.

Krauskopf, K. B., 1971, Geologic map of the Mount Barcroft quadrangle, California-Nevada: U.S. Geological Survey Geologic Quadrangle Map GQ-960, scale 1:62,500.

McKee, E. H., Diggles, M. F., Donahoe, J. L., and Elliott, G. S., 1982, Geologic map of the white Mountains Wilderness and roadless areas, California and Nevada: U.S. Geological Survey Miscellaneous Field Studies Map MF-1361-A, scale 1:62,500.

McKee, E. H., and Gangloff, R. A., 1969, Stratigraphic distribution of archaeocyathids from the Silver Peak and White and Inyo Mountains of western Nevada and eastern California: Journal of Paleontology, v. 43, p. 716-726.

Nelson, C. A., 1962, Lower Cambrian-Precambrian succession, White-Inyo Mountains, California: Geological Society of America Bulletin, v. 73, p. 139-144.

1966a, Geologic map of the Waucoba Mountain quadrangle, Inyo County, California: U.S. Geological 
Survey Geologic Quadrangle Map GQ-528, scale $1: 62,500$.

1966b, Geologic map of the Blanco Mountain quadrangle, Inyo and Mono Counties, California: U.S. Geological Survey Geologic Quadrangle Map GQ-529, scale $1: 62,500$.

Nelson, C. A., and Durham, J. W., 1966, Guidebook for field trip, Precambrian-Cambrian succession, White-Inyo Mountains, California: Geological Society of America, 79th Annual Meeting, San Francisco, Calif., 1966 (Paleontological Society Section), $17 \mathrm{p}$.

Norman, L. A., and Stewart, R. M., 1951, Mines and mineral resources of Inyo County: California Journal of Mines and Geology, v. 47, p. 17-223.

Rains, R. L., Horn, M. C., and Neumann, T. R., 1983, Mineral investigations of the Black Canyon RARE II Area (No. 5061), Inyo County, California: U.S. Bureau of Mines Open File Report MLA 85-83, 21 p.
Schmauch, S. W., Lipton, D. A., Gabby, P. N., Barnes, D. J., and Horn, M. C., 1982, Mineral investigations of the Blanco Mountain RARE II Area (No. 5059), Inyo and Mono Counties, California: U.S. Bureau of Mines Open File Report MLA 146-82, 12 p.

Streckeisen, A. L., 1976, To each plutonic rock its proper name: Earth Science Review, v. 12, p. 1-33.

Tucker, W. B., 1926, Inyo County, in Report XXII of the State Mineralogist: California State Mining Bureau, Mining in California, v. 22, p. 453-530.

Tucker, W. B., and Sampson, R. J., 1938, Mineral resources of Inyo county: California Journal of Mines and Geology, v. 36, p. 368-500.

U.S. Bureau of Mines and U.S. Geological Survey, 1980, Principles of a resource/reserve classification for minerals: U.S. Geological Survey Circular 831, 5 p.

Table 1.--Recorded production from lode deposits in the Black Canyon Roadless Area

[Data from U.S. Bureau of Mines files. N.R., not reported; underlined properties are outside the study area]

\begin{tabular}{|c|c|c|c|c|c|c|}
\hline Property & Year (s) & $\begin{array}{l}\text { Tons of } \\
\text { production }\end{array}$ & $\begin{array}{c}\text { Gold } \\
\text { (ounces) }\end{array}$ & $\begin{array}{l}\text { Silver } \\
\text { (ounces) }\end{array}$ & $\begin{array}{l}\text { Copper } \\
\text { (pounds) }\end{array}$ & $\begin{array}{c}\text { Lead } \\
\text { (pounds) }\end{array}$ \\
\hline$\frac{\text { Hope and Caro1 } \mathrm{J}^{1}}{\underline{\text { mine }}}$ & $1925-1951$ & 2,696 & 124.63 & 15,706 & 2,592 & 220,744 \\
\hline Gray Eagle mine ${ }^{2}$ & $1933-1940$ & 11 & 38.6 & 23 & 33 & N.R. \\
\hline$\frac{\text { Golden Mirage }}{2}$ & 1912 & 79 & 160.4 & 170 & N.R. & N.R. \\
\hline $\begin{array}{l}\frac{\text { Little Gem }}{2} \\
\text { (Georgia, X-Ray } \\
\text { mine) }\end{array}$ & $1891-1896$ & N.R. & 162 & N.R. & N.R. & N.R. \\
\hline Mariposa mine ${ }^{3}$ & $1954-1957$ & N.R. & N.R. & N.R. & N.R. & N.R. \\
\hline Poleta mine & $1892-1962$ & 6,049 & $3,842.7$ & 794 & N.R. & N.R. \\
\hline $\mathrm{R}$ and $\mathrm{R}$ mine ${ }^{3}$ & 1952 & $\mathrm{~N} \cdot \mathrm{R}$. & N.R. & N.R. & N.R. & N.R. \\
\hline $\begin{array}{l}\text { Trinity prospect } \\
\text { (Black Canyon } \\
\text { Consolidated mine) }\end{array}$ & N.R. & N.R. & N.R. & N.R. & N.R. & N.R. \\
\hline Totals & & 8,835 & $4,328.33$ & 16,693 & 2,625 & 220,744 \\
\hline
\end{tabular}

1 Tucker (1926) reported that 510 tons of lead-silver production was valued at $\$ 9,400$. This record is apparently incomplete; Bureau of Mines records indicate higher figures. Bureau records also show the Eagle properties had produced a total of 20 pounds of $z$ inc.

2 In 1912, five carloads of ore were shipped from the Gray Eagle, Golden Mirage, and X-Ray mines (Knopf, 1914).

3 Two properties, the $R$ and $R$ and the Mariposa, were reported to have produced tungsten. Bateman (1956) reported several thousand tons for the $R$ and $R$ claims, grade unknown. The owner of the Mariposa mine stated that the mine operated between 1954 and 1957 and that one month's production was 500 tons of unknown grade (Buzz Peregoy, written commun., 1981). Amounts for the rest of that time period are unknown.

4 Aubury (1904) reported unspecified production from the Black Canyon Consolidated mine, now known as the Trinity prospect. 
Table 2.--Mines, prospects, and mineralized areas in the Black Canyon and Blanco Mountain Roadless Areas [Underlined names refer to properties with resource potential; those not underlined have no potential or are poorly exposed and a determination oannot be made]

\begin{tabular}{|c|c|c|c|c|}
\hline $\begin{array}{l}\text { Map } \\
\text { No. }\end{array}$ & $\begin{array}{c}\text { Name } \\
\text { (oommodity) }\end{array}$ & Summary & $\begin{array}{l}\text { Workings and } \\
\text { production }\end{array}$ & $\begin{array}{l}\text { Sample data } \\
\text { and resouroes }\end{array}$ \\
\hline
\end{tabular}

1 White Rock

prospect

(gypsum)

Happy Day prospect (gold, silver)
Sand A Gold $\frac{\text { prospect }}{\text { (gold, silver) }}$ Ground Hog
prospect
(gold)

Barite Queen prospect (barite)

Jack Rabbit prospect (gold, silver)
Two white granular gypsum veins up to 0.8 $\mathrm{ft}$ thick are exposed $20 \mathrm{ft}$ along strike in recrystallized limestone. One vein strikes $\mathrm{N} .78^{\circ} \mathrm{E}$. and dips $75^{\circ} \mathrm{NW}$.; the other strikes N. $50^{\circ} \mathrm{W}$. and dips $60^{\circ} \mathrm{SW}$. Small selenite orystals are present in the gypsum vein.

A 3-ft-thick silty, $\infty$ litio recrystallized limestone crosscut by quartz veinlets oocurs along a shale-limestone contact. The contact strikes north and dips vertioally. Minor visible galena ocours in the recrystallized limestone.

Quartz veins up to $3 \mathrm{ft}$. thick trend northeast and dip $80^{\circ} \mathrm{NW}$. to vertically in hornfels and slate. They are masive, vuggy in places, and iron oxide stained along fractures. Pyrite, hematite after pyrite, and copper stains are also present.

Massive milky white quartz vein up to $5 \mathrm{ft}$ thick strikes N. $33^{\circ} \mathrm{E}$, and dips $70^{\circ} \mathrm{SE}$. in hornfels that strikes $\mathrm{N} .17^{\circ} \mathrm{E}$. and dips $25^{\circ} \mathrm{NW}$.

A vein of barite up to $1.7 \mathrm{ft}$ thick strikes north for $85 \mathrm{ft}$ and dips vertically in thin-bedded slate.

The Poleta mine lies on the southwest limb of an anticline that plunges steeply to the south. Country rook is thin-bedded limestone and phyllite. A quartz fissure vein, localized along a bedding plane, is located in the hanging wall of a zone of highly altered gouge that is up to $6 \mathrm{ft}$ thick. The vein strikes northeast, dips $20^{\circ}$ to $50^{\circ} \mathrm{NW}$, and ranges in thickness from 2 in. to $2.5 \mathrm{ft}$. Gold-bearing pyrite in the vein is altered to iron oxide pseudomorphs carrying free gold. The vein pinches out to the east and is truncated on the west by a highly brecciated fault zone that strikes northeast and dips $35^{\circ}$ to $45^{\circ} \mathrm{NW}$. (Bateman, 1956).

Fractured iron oxide-stained quartz veins up to $4 \mathrm{ft}$ thick strike $\mathrm{N}$. $40^{\circ}$ to $60^{\circ} \mathrm{E}$. and dip $25^{\circ}$ to $75^{\circ} \mathrm{SE}$. in granitoid rocks. The pyrite-bearing quartz veins are disoontinuous.

Quartz veins up to $1.0 \mathrm{ft}$ thiok strike northeast and northwest and dip $45^{\circ}$ to $60^{\circ} \mathrm{E}$. in quartz monzonite. The veins are fractured, iron oxide-stained, and have a trace of copper stain.

A small garnet-pyroxene-epidote tactite pod grades rapidly into quartz monzonite and limestone.
Two small prospeot pits are on the property. Two chip samples of gypsum contained no metal values.
Prospect workings consist of one shaft 15 ft deep, two trenches 25 and $44 \mathrm{ft}$ long, and one prospect pit.

Workings consist of four adits totalling $1,100 \mathrm{ft}$ (including $820 \mathrm{ft}$ of development in the lower adit) two shafts

totalling $90 \mathrm{ft}$, and three prospect pits.

One prospect pit is 5 by $8 \mathrm{ft}$.

One adit is $27 \mathrm{ft}$ lons and one trench is $20 \mathrm{ft}$ long.

Mine workings consist of 15 shafts, four adits, and numerous prospect pits; most shafts and adits are caved or ar less than $100 \mathrm{ft}$ long. The main working consists of a $400-\mathrm{ft}$ long adit with six levels and a 600-ft-deep winze. Bureau of Mines files show that about $5,000 \mathrm{oz}$ of gold and 1000 oz of silver have been produced between 1892 and 1961.

One adit $25 \mathrm{ft}$ long, one 10-ft-deep shaft, and three prospect pits explore the property.

Five adits, (four totaling $180 \mathrm{ft}$ in length and one caved), one 20-ft-long inclined shaft, and six prospect pits explore the property.

A 15- by 90-ft glory hole from which about 1,100 tons of material have been removed and a 4- by 8-ft deep prospect pit in limestone are on the property.

Two adits total $320 \mathrm{ft}$ in length, surface workings include several open cuts and two prospect pits. of three grab samples of siliceous limestone, two oontained 0.012 and 0.294 oz gold per ton and two had 0.46 to 11 percent lead. One contained 3.9 oz silver per ton. One chip sample of limestone contained $1.2 \mathrm{oz}$ silver per ton and 1.7 percent lead.

About 2800 tons of vein quartz averages $0.088 \mathrm{oz}$ gold per ton and $0.63 \mathrm{oz}$ silver per ton. Potential is moderate for goldsilver resources.

One chip and one grab sample of quartz contained no gold or silver.

Three chip samples of the barite vein contained 54.8 to 56.3 percent barium sulfide. One chip sample of slate contained no significant metal values.

Twenty-one chip and five grab samples were taken of quartz and shear zone: five chip samples of quartz assayed 0.066 to $1.10 \mathrm{oz}$ per ton gold; two grab samples of quartz oontained 0.124 to 0.616 oz gold per ton. Two chip samples and one grab sample of quartz contained 0.4 to $0.6 \mathrm{oz}$ silver per ton. Five chip samples of quartz contained 0.07 to 0.51 percent lead. Potential for gold-silver-lead resources

Four chip and three grab samples of quartz were taken; four oontained trace to 0.048 oz gold per ton, and three contained 0.3 to $1.0 \mathrm{oz}$ silver per ton.

There are about 10,400 tons of subeconomic resources with an average grade of $0.14 \mathrm{oz}$ gold per ton. The potential is low for additional gold resources.

One grab and four chip samples of tactite were taken; four oontained 0.3 to $0.4 \mathrm{oz}$ silver per ton and four contained from 0.04 to 0.62 percent tungsten trioxide Two samples of limestone contained 0.2 and $0.3 \mathrm{oz}$ silver per ton. One sample of quartz monzonfte contained $0.3 \mathrm{oz}$ silver per ton.

Nineteen chip and two grab samples were taken; of 16 chip samples of quartz, four contained 0.006 to 0.020 oz gold per ton, five contained 0.4 to $0.7 \mathrm{oz}$ silver per ton, and one contained $6.0 \mathrm{oz}$ silver per ton. Two chip samples of shear zone contained 0.016 and $1.344 \mathrm{oz}$ gold per ton, and one oontained $0.8 \mathrm{oz}$ silver per ton. One grab sample of quartz contained 0.228 oz gold per ton. 
Table 2.--Mines, prospects, and mineralized areas in the Black Canyon and Blanco Mountain Roadless Areas--Continued

\begin{tabular}{|c|c|c|}
\hline $\begin{array}{l}\text { Map } \\
\text { No. }\end{array}$ & $\begin{array}{c}\text { Name } \\
\text { (commodity) }\end{array}$ & Summary \\
\hline & & Black Canyon Roadless \\
\hline 11 & $\begin{array}{l}\text { Curiosity prospect } \\
\text { (gold) }\end{array}$ & $\begin{array}{l}\text { An iron oxide vein } 2.5 \mathrm{ft} \text { thiok strikes } \mathrm{N} \text {. } \\
75^{\circ} \mathrm{E} \text {. and dips } 70^{\circ} \mathrm{NW} \text {. in limestone. }\end{array}$ \\
\hline $12 *$ & $\begin{array}{l}\text { North Star } \\
\text { prospect } \\
\text { (gold, silver) }\end{array}$ & $\begin{array}{l}\text { Two fissure-filling quartz veins pinch and } \\
\text { swell to a maximum thickness of } 5 \mathrm{ft} \\
\text { within shear zones in quartz monzonite. } \\
\text { One vein strikes } \mathrm{N} \text {. } 35^{\circ} \mathrm{E} \text {., dips } 45^{\circ} \text { to } \\
75^{\circ} \mathrm{SE} \text {; the other strikes } \mathrm{N} \text {. } 65^{\circ} \mathrm{E} \text {. and } \\
\text { dips } 70^{\circ} \text { to } 85^{\circ} \mathrm{NW} \text {. They are moderately } \\
\text { iron oxide stained, generally fractured, } \\
\text { and locally mylonized. }\end{array}$ \\
\hline
\end{tabular}

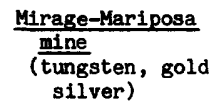

\section{Gray Eagle mine}

Gray Eagle No. 2 prospect (gold)

17
A $0.5 \mathrm{ft}$ thick quartz vein strikes N. $45^{\circ} \mathrm{W}$. and dips about $25^{\circ} \mathrm{NE}$ in quartz monzonite. The vein is fractured, heavily iron oxide- and copper-stained, and in places is composed of 50 to 60 percent iron oxides.
A contact metasomatic tactite body lies along an east-trending contact between quartz monzonite and limestone exposed for $500 \mathrm{ft}$. The tactite is composed of garnet, pyroxene, epidote, and calcite with minor amounts of pyrite, scheelite, and molybdenite. The tactite body is irregular and fingers out into the limestone. Several randomly oriented quartz veins up to $45 \mathrm{ft}$ thick occur in the quartz wonzonite.

East-striking quartz veins dip $35^{\circ} \mathrm{N}$. along the oontact of quartz monzonite and interbedded argilite and hornfels. Quartz veins contain pyrite, chalcopyrite, are vuggy, and have iron oxide and copper stains along fractures; veins are up to 3 $\mathrm{ft}$ thick and average about $2 \mathrm{ft}$ in thickness. In places iron oxides comprise 75 percent of the vein.

A 2-ft-thick east-trending shear zone dipping $35^{\circ}$ to $55^{\circ} \mathrm{N}$. occurs in limestone and hornfels.

Quartz veins 1 to $2 \mathrm{ft}$ thick striking north, dipping $50^{\circ}$ to $60^{\circ} \mathrm{W}$. occur in quartz monzonite.

A pod of iron oxide ocours in limestone that strikes N. $5^{\circ}$ E. and dips $85^{\circ} \mathrm{NW}$.

Limonite boxworks with quartz stringers occur in an irregular shear zone that trends northeast across beds of phyllite, quartzite, and limestone.

A siliceous, iron-rich zone $2.0 \mathrm{ft}$ thick strikes $\mathrm{N} .70^{\circ} \mathrm{W}$. and dips $75^{\circ} \mathrm{NE}$. in dolomite. Milky white quartz with traces of galena was found in a small stockpile.
The adit has three levels conneoted by a winze. There are over $700 \mathrm{ft}$ of workings. Four other adits are caved and a line of pits and trenohes explore the vein along the surface. Between 1891 and 1896, 162 oz of gold were shipped from the property

A glory hole from which about 20,000 tons of material was removed and a $20 \mathrm{ft}$ and a $45 \mathrm{ft}$ adit driven along the quartz monzonite-limestone contact are present on the property. In 1916, 79 tons of ore ylelded $160.4 \mathrm{oz}$ gold and $170 \mathrm{oz}$ silver. Several thousand tons of tungsten ore were mined between 1952 and 1957.

Workings consist of three adits: one is caved and the other two aggregate $400 \mathrm{ft}$ of development. In 1912, ore from the Gray Eagle mine was combined with ore from the Golden Mirage and Little Gem (X-Ray) mine. From 1933 to 1940,11 tons of ore to 1940, 11 tons of ore, oontaining 38.6 oz gold,
$21 \mathrm{oz}$ silver, and $33 \mathrm{lb}$ of copper, was produced.

One adit is $60 \mathrm{ft}$ long.

One 15-ft-long inclined shaft and three prospeot pits explore the veins.

There are two prospect pits: one 5 by $6 \mathrm{ft}$, the other 3 by $3 \mathrm{ft}$.

Prospect workings consist of one adit 25 ft long and five prospeot pits.

One small pit is located on the property.
One chip sample and one grab sample of iron oxides oontained no significant metal values.

Twenty-four ohip samples were taken of quartz and shear zones and one select sample of quartz was collected. The later contained $0.036 \mathrm{oz}$ gold per ton and three chip samples of quartz contained 27.4 , 4.7 , and $1.7 \mathrm{oz}$ silver per ton.

About 3,600 tons of subeconomic resources averaging $1.2 \mathrm{oz}$ gold per ton are estimated to be on the property.

Potential for additional gold resouroes is moderate.

About 55,000 tons of subeconomic tungsten resources with an average grade of 0.15 percent tungsten trioxide are present on the property. Potential for additional tungsten resouroes is moderate. About 160 tons with $0.34 \mathrm{oz}$ silver per ton are present in the quartz veins.

About 4,700 tons of vein quartz averages $1.3 \mathrm{oz}$ silver per ton and $0.026 \mathrm{oz}$ gold per ton. Potential for silver-gold resources is high.

Five chip samples of hornfels contained no gold or silver. One sample of hornfels contained 0.2 oz silver per ton.

One grab and two chip samples of quartz were collected; the grab sample contained 9.5 oz silver per ton; one chip sample contained 0.9 oz silver per ton.

One chip and one grab sample of iron oxides contained no signifioant metal values.

of four chip samples of the shear zone, three contained 0.3 to 0.5 oz silver per ton. One grab sample of iron oxide boxwork contained 9.7 oz silver and 0.086 oz gold per ton. Another contained $0.4 \mathrm{oz}$ silver per ton. One chip and one grab sample of quartzite contained no metal values.

One select sample of quartz oontained 0.3 oz silver per ton and 0.20 peroent lead. One chip sample of shear zone contained $0.014 \mathrm{oz}$ gold per ton. 
Table 2.--Mines, prospects, and mineralized areas in the Black Canyon and Blanco Mountain Roadless Areas---Continued

\begin{tabular}{|c|c|c|c|c|}
\hline $\begin{array}{l}\text { Map } \\
\text { No. }\end{array}$ & $\begin{array}{c}\text { Name } \\
\text { (commodity) }\end{array}$ & Summary & $\begin{array}{l}\text { Workings and } \\
\text { production }\end{array}$ & $\begin{array}{l}\text { Sample data } \\
\text { and resouroes }\end{array}$ \\
\hline
\end{tabular}

Black Canyon Roadless Area--Continued

\begin{tabular}{|c|c|c|c|c|}
\hline 21 & $\begin{array}{l}\text { Brown Mule } \\
\text { prospect } \\
\text { (gold, silver) }\end{array}$ & $\begin{array}{l}\text { A } 135-\text { by } 15-f t \text { vertical pod of milky- } \\
\text { white massive quartz trends northwest and } \\
\text { dips vertioally. Thin-bedded, } \\
\text { argillaceous limestone country rock }\end{array}$ & $\begin{array}{l}\text { One open cut is } 15 \mathrm{ft} \\
\text { long. }\end{array}$ & $\begin{array}{l}\text { of four chip samples of quartz, one } \\
\text { contained } 3.3 \text { oz silver per ton, and } \\
\text { another contained } 0.078 \text { oz gold per to }\end{array}$ \\
\hline
\end{tabular}

$22 \quad$ Buster prospect (gold, silver)

Jody-Dee-Tom

prospect

(gold)

Siliceous fissure veins and quartz veins up to $4.5 \mathrm{ft}$ wide occur along northwesttrending faults in hornfels and limestone.

North striking shear zones dip generally west and oocur in massive gray limestone that strikes N. $30^{\circ} \mathrm{W}$. and dips $50^{\circ}$ to $60^{\circ}$ SW. The zone forms irregular lenses in veins of geothite, limonite, and hematite with visible galena are from 1 to $4 \mathrm{ft}$ thick. Heavily oxidized zones up to $40 \mathrm{ft}$ thick are exposed underground.

A 1- to 2-ft-thiok iron oxide zone strikes N. $60^{\circ} \mathrm{W}$. , dips vertically in limestone, and is terminated by a limestone-quartzite contaot that strikes $\mathrm{N} .10^{\circ} \mathrm{W}$. and dips $80^{\circ} \mathrm{SW}$.
One shaft $35 \mathrm{ft}$ deep and three small prospect pits explore vein.

One adit is $57 \mathrm{ft}$ long.

Workings consist of one inclined shaft $12 \mathrm{ft}$ deep and one small prospect pit.

Property development consists of one 540-ftlong adit, three shafts (all collapsed), and 12 prospect pits. Bureau of Mines records show that 2,696 tons of ore, yielded 124.63 oz gold, 15,706 oz silver, 2,592 Ib copper, 220,744 1b lead, and $20 \mathrm{lb}$ zinc was produced from 1925 to 1951.

A 60-ft-long adit two, 20-ft-long adits, a 20ft-long open out, and two pits investigated the property.

Two caved shafts, one trench, and two small prospect pits are present on the property.

Workings on the property oonsist of two adits with $500 \mathrm{ft}$ of drifts, inclined stopes, and winzes. There are three shafts; one is caved, the others are 12 and 22 ft deep. Between 1925 and 1946,900 tons of high-grade lead-silver ore was shipped. In 1947,248 tons yielded $6.6 \mathrm{oz}$ silver per ton and 7.7 percent lead.

Development consists of two shafts, 40 and $25 \mathrm{ft}$ deep, one 50-ft adit, one inaccessible adit, a 60-ft-long open cut, and one small prospect pit.

One shaft $20 \mathrm{ft}$ deep is looated on the property.
Three chip and one grab sample of the iron oxide-rich vein contained trace to 0.110 oz gold per ton and two contained 1.0 and $6.4 \mathrm{oz}$ silver per ton.

Four chip samples of shear zone contained no significant metal values.

Two chip samples of shear zone and one chip sample of dolomite contained no metal values.

There are about 31,000 tons of subeconomic resources with an average grade of $0.07 \mathrm{oz}$ gold per ton and $3.6 \mathrm{oz}$ silver per ton on the property. Potential for additional gold-silver-lead-copper resources is moderate.

About 8,800 tons of subeconomic resouroes with an average grade of $0.01 \mathrm{oz}$ gold per ton, 3.8 oz silver per ton and 1.0 percent lead are present. Potential for goldsilver-lead resources is moderate.

of seven samples, two chip samples of iron oxides contain no metal values. Of five chip and grab samples of limestone collected; three contained 1.0 to 2.9 oz silver per ton.

About 84,000 tons of indicated and inferred subeconomic resources with an average grade of 2.0 silver per ton, 1.0 percent lead, and 2.2 percent zine are present on the property.

Five chip samples of quartz contained no significant metal values.

One chip sample of iron oxides contained no significant metal values. 
Table 2.--Mines, prospects, and mineralized areas in the Black Canyon and Blanco Mountain Roadless Areas--Continued

\begin{tabular}{|c|c|c|c|c|}
\hline $\begin{array}{l}\text { Map } \\
\text { No. }\end{array}$ & $\begin{array}{c}\text { Name } \\
\text { (commodity) }\end{array}$ & Summary & $\begin{array}{l}\text { Workings and } \\
\text { production }\end{array}$ & $\begin{array}{l}\text { Sample data } \\
\text { and resources }\end{array}$ \\
\hline \multicolumn{5}{|c|}{ Black Canyon Roadless Area--Continued } \\
\hline
\end{tabular}

hematite, from 1.0 to $6.0 \mathrm{ft}$ thick with occurrences of fractured quartz veinlets. is emplaced between overlying limestone and underlying quartzite west of fault.

32

33

34
Vulcan prospect (gold)

Golden Nugget (grospect

Triple Canyon prospect (silver, lead)

\section{Hal1 Extension} mine (silver-lead)

\section{Lone Chair} prospect (lead, zinc)

Fay prospect
(gold)

Crown $K$
$($ lead)

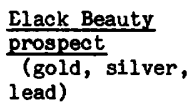

Discontinuous milky-white quartz veins up to $0.5 \mathrm{ft}$ thick strike $\mathrm{N} .50^{\circ} \mathrm{W}$. and dip vertically in hornfels that strike $N .60^{\circ}$ E. and dip $15^{\circ} \mathrm{NW}$.

An iron oxide-stained shear zone strikes N. $30^{\circ} \mathrm{W}$, , dips $48^{\circ} \mathrm{NE}$. in limestone that strikes $\mathrm{N}$. $20^{\circ} \mathrm{W}$. and dips $55^{\circ} \mathrm{NE}$.

A massive milky-white quartz vein, exposed for $75 \mathrm{ft}$, strikes $N .60^{\circ} \mathrm{W}$. and dips vertically in fine-grained massive-bedded dolomite. The quartz vein has minor visible galena, is vuggy, and has minor iron oxide staining along fraotures.

A 0.7-ft-thick quartz vein in limestone strikes N. to $\mathrm{N} .55^{\circ} \mathrm{E}$. and dips $20^{\circ} \mathrm{SE}$. The milky-white, fraotured quartz vein contains 4-in. blebs of medium-grained galena and is offset by several small faults. A fault whioh strikes north and dips vertically terminates the quartz vein.

Fissure filling of specular hematite, limonite, and quartz occur for over $40 \mathrm{ft}$ within a northwest trending shear zone that is up to $5 \mathrm{ft}$ thiok in interbedded limestone and phyllite that strike N. $15^{\circ}$ W. and dip $40^{\circ} \mathrm{SW}$.

A 2.5-ft-thiok quartz vein strikes N. $54^{\circ}$ E. and is exposed for $8 \mathrm{ft}$ along strike. The quartz vein is massive, iron oxidestained, and has hematite after pyrite pseudomorphs.

A 1- to 2.5-ft-thick shear zone strikes $N$. $10^{\circ} \mathrm{E} .$, dips vertically to $45^{\circ} \mathrm{SE}$. in fine-grained, medium-bedded quartzite and interbedded gray recrystallized

limestone. Within the shear zone are numerous quartz veinlets and blebs which range up to $1 / 2$ in. in thickness and contain fine-grained galena and pyrite.

Country rook is composed of interbedded limestone and phyllite striking north with near-vertical dips. Two north striking, steeply-dipping veins occur as fissurefilled zones of friable iron oxides and quartz 5 in. to $3 \mathrm{ft}$ thick with interbedded veinlets of galena up to 1.5 in. thick. North striking faults dipping
$55^{\circ}$ to $85^{\circ}$ W. truncate the veins downdip.

Quartz pods up to 1.0 by $5.0 \mathrm{ft}$ occur in phyllite that strikes N. $10^{\circ} \mathrm{W}$. and dips

A silicified, heavily iron oxide-stained zone up to $3.0 \mathrm{ft}$ thiok strikes N. $45^{\circ} \mathrm{E}$. and dips $30^{\circ}$ to $60^{\circ} \mathrm{SE}$. in limestone.

A shear zone st."ikes N. $30^{\circ}$ E., and dips $45^{\circ}$ SE. in limastone that strikes N. $35^{\circ}$ $E$, and dips ve: :ically.
A dump from a possible caved adit and one small prospect pit are present on the property.

one $43 \mathrm{ft}$-long adit is located on the property.

Four adits totaling 180 ft of workings and one small pit are on the property.

Four adits totaling $180 \mathrm{ft}$ of workings and one small pit are located on the property.

A 20-ft-long adit with a 40-ft-deep winze, a 40ft-long trench, and two prospeot pits explore the vein.

One 8-ft-diameter, $2 \mathrm{ft}$ deep prospeot pit is located on the property.

Two inclined shafts $75 \mathrm{ft}$ and $12 \mathrm{ft}$ deep and a 45-ft-long adit follow $300 \mathrm{ft}$ of shear zone.

Two adits totaling 340 ft long and one inolined shaft $45 \mathrm{ft}$ deep are looated on the property.

One prospect pit explores one pod.

One adit $32 \mathrm{ft}$ long and a 10- by 15-ft prospect pit are located on the property.

One shaft $10 \mathrm{ft}$ deep and two small pits explore the property.
Two grab samples of quartz oontained no significant metal values.

One chip sample of the shear zone and one random ohip sample of limestone contained no significant metal values.

Approximately 1,200 tons of subeconomic resources with an average grade of $5.4 \mathrm{oz}$ silver per ton and 3.6 percent lead.

Approximately 1,200 tons of vein quartz average $5.4 \mathrm{oz}$ silver per ton and 3.6 percent lead. Potential for silver-lead resouroes is low.

of seven ohip and three grab samples, one grab sample of quartz contained 1.98 peroent lead and 0.24 peroent zino, and one chip sample of sheared limestone oontained 0.39 percent lead.

One chip and one grab sample of quartz contained no significant metal values.

Eight chip samples and two grab samples of quartz, quartzite, and limestone were taken. One grab sample of quartz contaińs $0.2 \mathrm{oz}$ silver per ton and nine samples average 0.25 percent lead.

About 1,700 tons of indicated and inferred subeconomio resources with an average grade of $0.18 \mathrm{oz}$ gold per ton and 1.2 percent lead are estimated. Some shoots have more than 4.0 oz silver per ton and 25 percent lead. Potential for goldsilver-lead resources is moderate.

One grab sample of quartz contained no significant metal value.

of three chip samples of silicified limestone, two oontained 0.81 and 1.7 percent lead.

Two ohip samples of the shear zone contained 0.7 and $0.3 \mathrm{oz}$ silver per ton. Two chip samples of the limestone contained 0.3 and $0.4 \mathrm{oz}$ silver per ton. 
Table 2.--Mines, prospeots, and mineralized areas in the Black Canyon and Blanoo Mountain Roadless Areas--Continued

\begin{tabular}{|c|c|c|c|c|}
\hline $\begin{array}{l}\text { Map } \\
\text { No. }\end{array}$ & $\begin{array}{l}\text { Name } \\
\text { (commodity) }\end{array}$ & Suminary & $\begin{array}{l}\text { Workings and } \\
\text { production }\end{array}$ & $\begin{array}{l}\text { Sample data } \\
\text { and resouroes }\end{array}$ \\
\hline \multicolumn{5}{|c|}{ Blanco Mountain Roadless Area } \\
\hline 43 & $\begin{array}{l}\text { Blizzard } \\
\text { extension } \\
\text { prospect } \\
\text { (gold) }\end{array}$ & $\begin{array}{l}\text { Fraoture zones in a north-trending } \\
\text { dolomite-granite contact contain } \\
\text { irregular, small quartz veins with local } \\
\text { concentrations of hematite and limonite. }\end{array}$ & $\begin{array}{l}\text { A } 28-f t-1 \text { ong adit, two } \\
\text { caved adits, and two } \\
\text { pits explore the } \\
\text { property. }\end{array}$ & $\begin{array}{l}\text { Two chip samples oontained } 0.3 \text { and } 0.5 \mathrm{oz} \\
\text { silver per ton. Two of the five seleot } \\
\text { samples had as much as } 0.452 \text { oz gold per } \\
\text { ton and } 2.6 \text { oz silver per ton. }\end{array}$ \\
\hline 44 & $\begin{array}{l}\text { Eolipse prospect } \\
\text { (silver, lead, } \\
\text { zinc) }\end{array}$ & $\begin{array}{l}\text { Fractured argillite is dissected by } \\
\text { several quartz veins and veinlets with } \\
\text { oellular siliceous limonite lenses up to } 7 \\
\text { in. thick and } 1 \mathrm{ft} \text { long. Quartz has } \\
\text { isolated conoentrations of galena and } \\
\text { pyrite. }\end{array}$ & $\begin{array}{l}\text { One trench is located in } \\
\text { argillite. }\end{array}$ & $\begin{array}{l}\text { Two chip and three grab samples were } \\
\text { collected. Grab samples had as muoh as } \\
0.4 \mathrm{oz} \text { silver per ton, } 0.44 \text { peroent lead, } \\
\text { and } 0.32 \text { peroent zinc. }\end{array}$ \\
\hline 45 & $\begin{array}{l}\text { Favor No. } 1 \\
\text { prospect } \\
\text { (gold) }\end{array}$ & $\begin{array}{l}\text { Hydrothermally altered, limonite-filled } \\
\text { zone along contaot between phyllite and } \\
\text { limestone striking N. } 16^{\circ} \text { E. and dips } 50^{\circ} \\
\text { NW. }\end{array}$ & $\begin{array}{l}\text { Two pits are present on } \\
\text { a phyllite-limestone } \\
\text { contact. }\end{array}$ & $\begin{array}{l}\text { Two grab samples were taken, one from the } \\
\text { limonite-filled zone, one from phyllite } \\
\text { with quartz fragments. The highest assay } \\
\text { value in the zone was } 0.01 \text { oz gold per } \\
\text { ton. }\end{array}$ \\
\hline 46 & $\begin{array}{l}\text { Hidden Treasure } \\
\text { prospeot } \\
\text { (gold, silver, } \\
\text { lead, zino) }\end{array}$ & $\begin{array}{l}\text { Heavily iron-stained bluish quartz vein } \\
\text { with euhedral quartz crystals strikes } \mathrm{N} \text {. } \\
80^{\circ} \mathrm{E} \text {. and dips } 85^{\circ} \mathrm{SE} \text {. Country rock is a } \\
\text { fractured, thin-bedded, phyllitic hornfels } \\
\text { striking } \mathrm{N} .25^{\circ} \mathrm{E} \text {. and dipping } 65^{\circ} \mathrm{NW} \text {. } \\
\text { with fracture fillings of pyrite, } \\
\text { arsenopyrite, and galena up to } 3 \text { in. } \\
\text { wide. Mineralized fractures are not } \\
\text { traceable beyond pit limits. }\end{array}$ & $\begin{array}{l}\text { One pit is located in } \\
\text { hornfels. }\end{array}$ & $\begin{array}{l}\text { Quartz vein samples had as much as } 0.17 \\
\text { peroent lead and } 0.11 \text { percent zinc. A } \\
\text { chip sample of the country rock had } 0.014 \\
\text { oz gold and } 3.0 \text { oz silver per ton, } 2.83 \\
\text { peroent lead, and } 9.2 \text { percent arsenic. } \\
\text { The zinc value from a grab sample was } 0.19 \\
\text { percent. }\end{array}$ \\
\hline
\end{tabular}

$47 \quad$ Insulation prospect
(gold)

$S$ and $S$ Nos. 1-8 prospect

(silver, lead)

Blue Bird Nos. 12 prospect (gold, placer)

Old Gold prospeot (gold)

\section{White Cloud}

prospect

(lead, zinc) traceable beyond pit limits.

A 1- to 2-ft-thick quartz vein strikes $\mathrm{N}$. $26^{\circ} \mathrm{E}$. and dips $71^{\circ} \mathrm{SE}$. in interbedded argillite and limestone.

Limestone with phyllite interbeds strikes N. $6^{\circ}-16^{\circ}$ E., dips $72^{\circ}-87^{\circ}$ SE., and includes a network of small, irregular quartz veins. Quartz has isolated ooncentrations of disseminated galena and pyrite.

A 1.8 - to 3.4-ft-thick quartz vein $65 \mathrm{ft}$ long and an irregular quartz pod about 10 ft wide and $20 \mathrm{ft}$ long occur in granite. Areas of the pod are brecciated and rehealed with brown jasper. A small xenolith of argillaceous limestone borders the pod and thin, undefined exposures of garnet-epidote skarn border portions of the quartz vein. Vuggy portions of the brecciated quartz contain euhedral quartz crystals, pyrite, and galena cubes.

Several areas also have very light malaohite staining.

Remnant Tertiary gravels composed of quartzite, dacite, gabbro, and granite clasts occur over a 4,000 ft by $1,000 \mathrm{ft}$ area. Thickness varies from a few feet to about $300 \mathrm{ft}$.

Deposit consists of limonite stained argillite.

Light-gray marbleized limestone and pale green-gray phyllite strike N. $15^{\circ}-30^{\circ} \mathrm{W}$. and dip $60^{\circ}$ SW. A shear zone 1.0 to 1.5 $\mathrm{ft}$ wide is partly traoeable for $100 \mathrm{ft}$. It oonsists of altered country rocks, siliceous limonite, gray chert, vein quartz, and hematite. The zone ranges from brecciated to vuggy and cellular. Highly oxidized blebs of galena and intergrown sphalerite are disseminated in the quartz.

Argillite, sandstone, and interbedded limestone strike $\mathrm{N} .16^{\circ}$ to $45^{\circ} \mathrm{E}$. and dip $63^{\circ} \mathrm{NW}$. Three small lenses or pods of hydrothermally-altered, iron-rich resilicified sediments contained oxidized galena. The largest pod is $4.3 \mathrm{ft}$ long and $3 \mathrm{ft}$ wide.
Workings oonsists of two pits.

A bulldozer cut, a trench, a pit, and an 18-ft-long adit are looated on the property.

Workings consist of three trenohes; the largest is $30 \mathrm{ft}$ long.

Workings oonsist of 13 trenches and pits, and two caved adits

One pit is located in argillite.

Workings consist of two pits: the largest is 30 $\mathrm{ft}$ long and $12 \mathrm{ft}$ wide.

Three pits explore the property .
Two chip and two grab samples oontained no signifioant metal values.

Seventeen chip and seven grab samples were taken. Samples contained as muoh as 5.5 oz silver per ton, 4 percent lead, and 0.16 percent tungsten trioxide, but most had considerably less.

Seven samples were collected. A random grab and three chip samples across the quartz vein had no significant metal values, but a select sample from a 2-ton stockpile had 0.02 oz gold per ton, $0.6 \mathrm{oz}$ silver per ton, 0.02 peroent copper, 0.16 percent lead, and 0.10 percent zinc. A random chip sample from the quartz pod contained $2.5 \mathrm{oz}$ silver per ton, 0.03 percent copper, and 0.06 percent lead.

Eleven grab samples were collected; none had reooverable gold.

One grab sample was collected; there is no deteotable gold or silver.

Three chip samples taken across the shear zone contained from 0.03 to 0.88 percent lead and from 0.42 to 0.64 peroent zino. Three stockpiles totaling about 5 tons were sampled. The two grab samples had 6.90 and 1.42 percent lead and 0.56 and 0.88 peroent zinc, respectively.

A chip sample from each pod and a random grab from each dump was taken. Two chip samples had 3.31 and 5.90 percent lead. A sample from a 1-ton stockpile located near the highest-grade pod had 9.60 percent lead. One chip sample also contained 0.4 percent zino.

\footnotetext{
${ }^{1}$ Numbers in parenthesis refer to township, range, and section, acoording to the Mount Diablo Meridian.
}

"Properties located near, but outside the roadless area. 


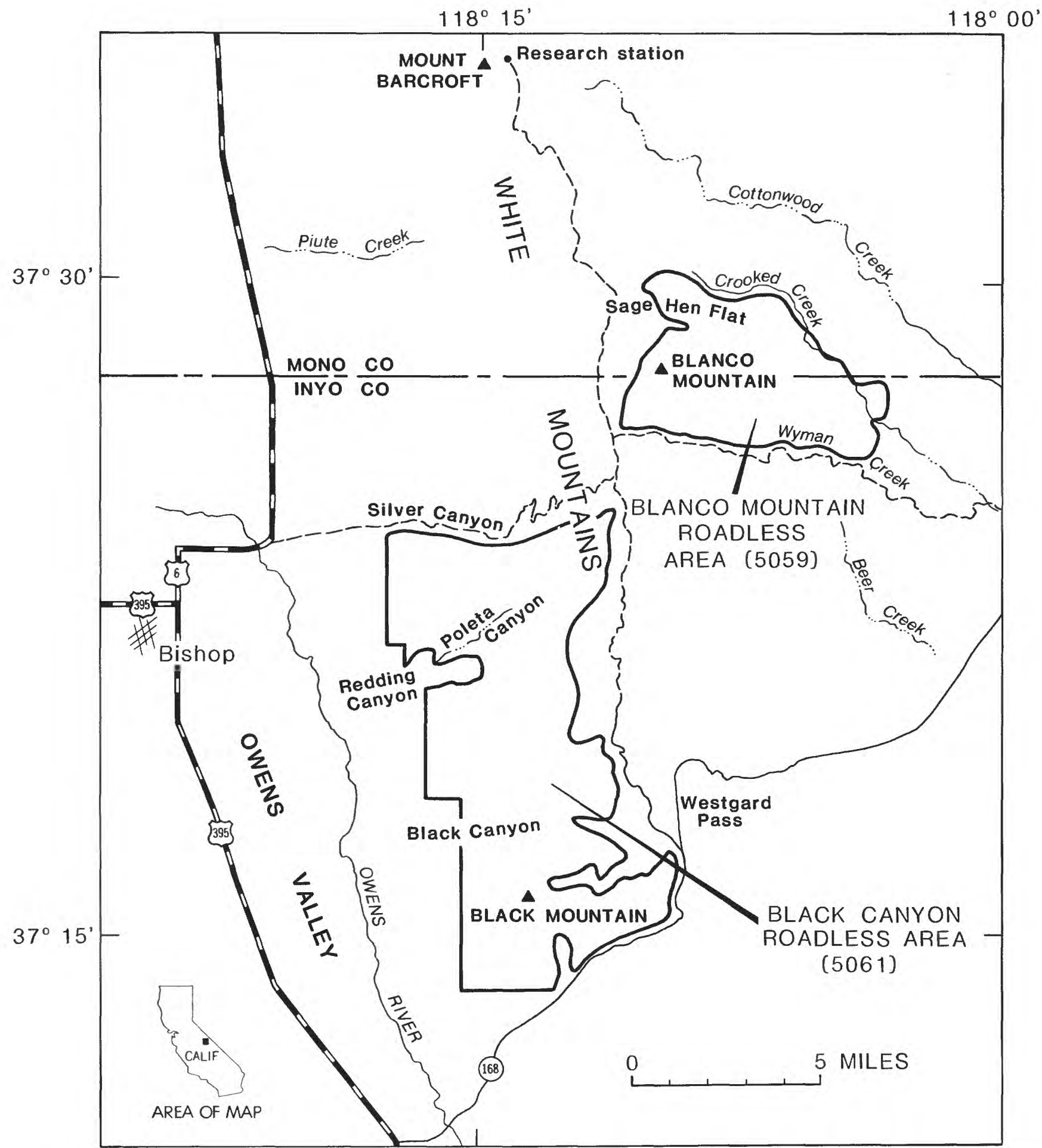

Figure 1.-- Index map showing locations of the Blanco Mountain (5059) and Black Canyon (5061) Roadless Areas in Inyo National Forest, Inyo and Mono Counties, California. 


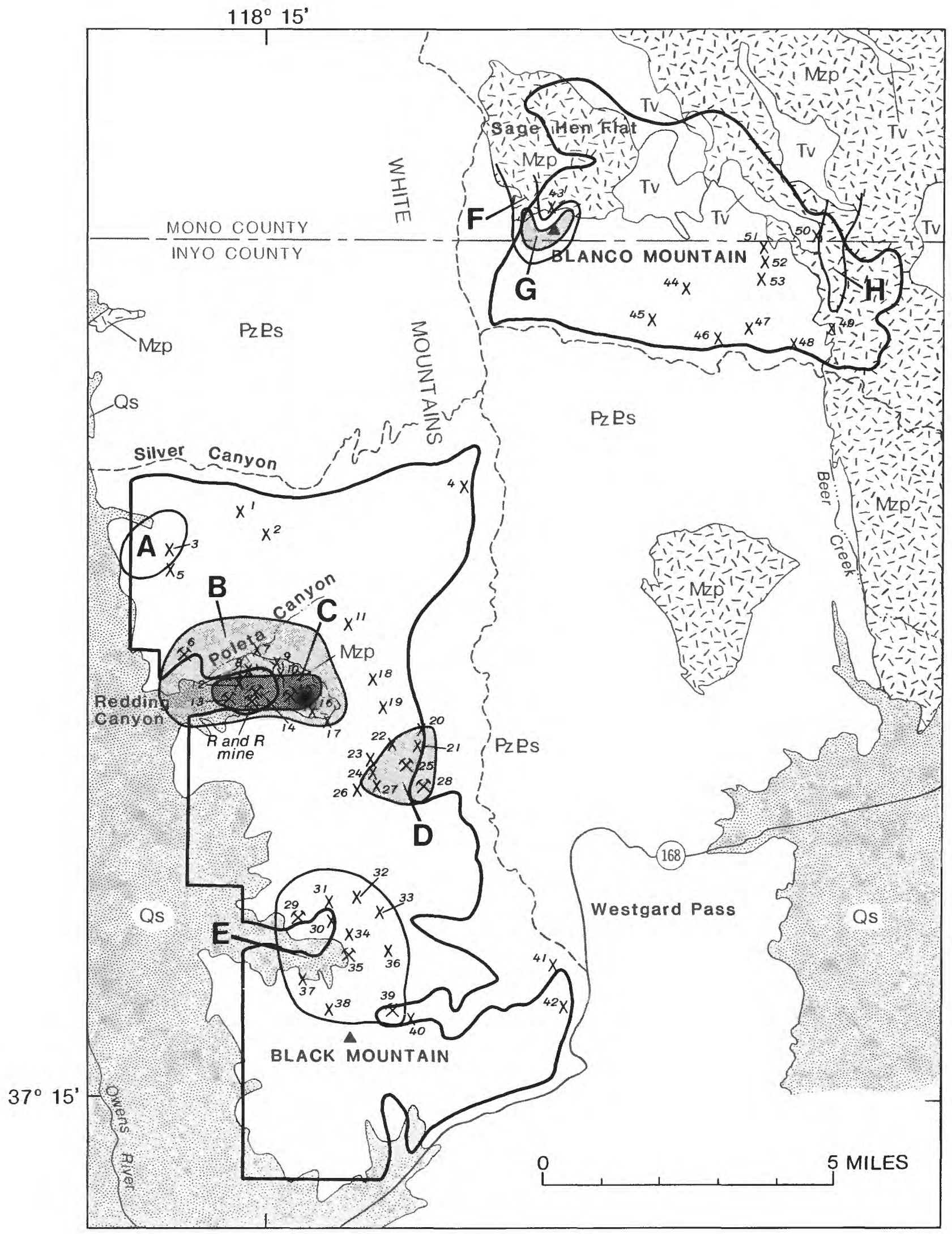

Figure 2.--Map showing generalized geology, mines and prospects, and areas of mineral resource potential in the Blanco Mountain and Black Canyon Roadless Areas, California (see explanation on following page). 


\section{EXPLANATION}

Areas with mineral resource potential--Labeled $\mathrm{A}-\mathrm{H}$

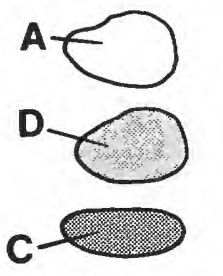

Area of low potential

Area of moderate potential

Area of high potential

${ }^{42} \times$ Prospect--Number refers to table 2

${ }^{14} x$ Mines with production record--Number refers to table 2

- Approximate boundary of roadless areas

- - - Secondary roads

DESCRIPTION OF MAP UNITS

Q.). Surficial deposits (Quaternary)

TV Volcanic rocks (Tertiary)

Elíp'-1 Plutonic rocks (Mesozoic)

PzEs Sedimentary rocks (Paleozoic and Proterozoic) 
